$$
\text { LA-SUB--95-175-A:I }
$$

SEA No. 90-500-02-A:1

\title{
FIFBR:
}

\section{REVIEW OF THE TECHNICAL SPECIFICATIONS AGAINST THE FSAR}

\author{
January 12, 1990 \\ (Revised January 25, 1990)
}

\author{
Prepared for: \\ Mr. P. R. Shire \\ Los Alamos IVational Laboratory \\ N-Division, MS K557 \\ P.O. Box 1663 \\ Los Alamos, NM 87545
}

Prepared by:

Dasari V. Kao, Steven B. Ross, Eddie R. Claiborne, John L. Darby, Robert A. Clark Science and Engincering Associates, Inc.

SEA Plaza

6100 Üptown Blvd. NE, Suite 700

Albuquerqque, NM 87110
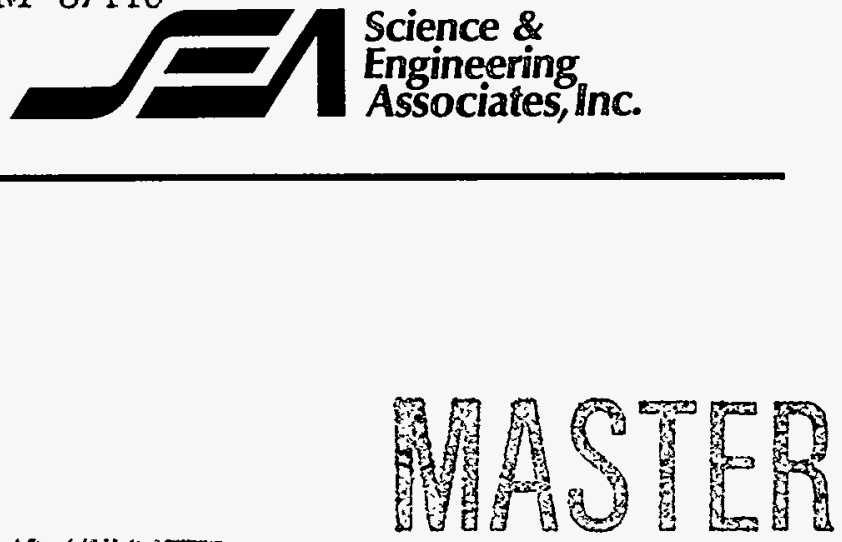


\section{DISCLAIMER}

Portions of this document may be illegible in electronic image products. Images are produced from the best available original document. 
SEA No. 90-500-02-A:1

\title{
HFBR:
}

\section{REVIEW OF THE \\ TECHNICAL SPECIFICATIONS AGAINST THE FSAR}

\author{
January 12, 1990 \\ (Revised January 25, 1990)
}

\author{
Prepared for: \\ Mr. P. R. Shire \\ Los Alamos National Laboratory \\ N-Division, MS K557 \\ P.O. Box 1663 \\ Los Alamos, NM 87545
}

Prepared by:

Dasari V. Rao, Steven B. Ross, Eddie R. Claiborne, John L. Darby, Robert A. Clark Science and Engineering Associates, Inc.

SEA Plaza

6100 Uptown Blvd. NE, Suite 700

Albuquerque, NM 87110

\section{DISCLAIMER}

This report was prepared as an account of work sponsored by an agency of the United States Government. Neither the United States Government nor any agency thereof, nor any of their employees, makes any warranty, express or implied, or assumes any legal liability or responsibility for the accuracy, completeness, or usefulness of any information, apparatus, product, or process disclosed, or represents that its use would not infringe privately owned rights. Reference herein to any specific commercial product, process, or service by trade name, trademark, manufacturer, or otherwise does not necessarily constitute or imply its endorsement, recommendation, or favoring by the United States Government or any agency thereof. The views and opinions of authors expressed herein do not necessarily state or reflect those of the United States Government or any agency thereof. 


\section{EXECUTIVE SUMMMARY}

The purpose of this review is to determine the adequacy of the High Flux Beam Reactor (HFBR) Technical Specifications for $40 \mathrm{MW}$ operation by comparison with the HFBR Final Safety Analysis Report, particularly the accident analyses chapter. Specifically, the Technical Specifications were compared against the Design Basis Accident (DBA) Analyses presented in the Addendum to the HFBR FSAR for $60 \mathrm{MW}$ Operation. The $60 \mathrm{MW}$ DBA analyses was used since it is more current and complete than the analyses presented in the original FSAR which is considered obsolete. A listing of the required systems and equipment was made for each of the accidents analyzed. Additionally, the Technical Specification instrument setpoints were compared to the DBA analyses parametric values.

Also included in this review was a comparison of the Technical Specification Bases against the FSAR and the identification of any differences. The HFBR Operations Procedures Manual (OPM) was also reviewed for any inconsistencies between the FSAR or the Technical Specifications.

Upon completion of this review it was determined that the Technical Specifications are well written and the items commented on should not delay the low power restart ( $40 \mathrm{MW})$. Additionally, the OPM is also well written and does not require further modification before restart.

The review also indicates that the systems and components required to mitigate the DBA discussed in HFBR-FSAR are automated, in almost all cases. The systems/components that are controlled manually from the control room provide first and second level redundancy. Thus operator actions provide a backup that is only needed in case of failure of the automated systems. The only exception to this is a LOCA in the primary system where the operator actions are essential to isolate the break and mitigate the accident. From the accident analysis is is clear that the HFBR is equipped with systems and equipment that are capable of mitigating a wide variety of accidents. Consequently, no major modifications are suggested for low power restart. The only modification suggested pertains to steam vent valves $P-300 \mathrm{~A} \& B$. It is recommended that for low power restart (40 MW) steam vent valves $P-300 A \& B$ be modified for remote manual operation and for $60 \mathrm{MW}$ operation they be modified to be fully automated in the event of a vessel or beam tube break. However, it is important to note that in spite of full automation of valves P-300 A\&B at $60 \mathrm{MW}$, the control room and operations level may be inaccessible during accidents for any manual mitigating actions (poison solution addition) due to the high radiation levels; therefore core damage may result. Additionally, although the pony motors are not required for low power restart they should be included as another level of forced cooling redundancy. 


\section{SCOPE OF THE REVIEW}

The purpose of this task is to perform a review of the HFBR Technical Specifications to determine their adequacy for $40 \mathrm{MW}$ operation. This review involved the following activities:

- Development of a listing of all systems and equipment required by the FSAR Design Basis Accident (DBA).

- Comparison of the HFBR Technical Specifications with the list in item 1.

- Identification of cases where the Technical Specifications are not in agreement with the DBA analyses parametric values.

- Review of the HFBR Technical Specifications against the FSAR to determine any inconsistencies.

- Review of the HFBR Operations Procedure Manual (OPM)

\section{METHODOLOGY}

To accomplish this task the following documents were utilized:

- HFBR Final Safety Analysis Report (FSAR) Volumes I and II

- Addendum to the HFBR FSAR, 1978

- Addendum to the HFBR FSAR for 60 MW Operation, 1982

- HFBR Plant Description Manual

- HFBR Operations Procedures Manual

- HFBR Technical Specifications and References (60 MW and $40 \mathrm{MW}$ Operation) February 1989

- Level I Internal Event PRA for the HFBR Volume I: Summary and Results

- Level I Internal Event PRA for the HFBR Volume II: Summary and Results 


\section{DETAIL}

The details of the review are presented in the following two sections. The first of these sections presents the details of the review of the HFBR technical specifications. The latter section presents discussions concerning the list of systems and components required by the HFBR FSAR DBA .

\section{IV.1 REVIEW OF THE HFBR TECHNICAL SPECIFICATIONS}

The Technical Specifications define the boundaries for safe operation for the High Flux Beam Reactor. Additionally, the Technical Specifications provide the basis for the development of rules, limits and procedures contained in the HFBR Operations Procedures Manual (OPM). The HFBR FSAR and its addenda contain the safety analysis of the HFBR which sets the guidelines for the establishment of the reactor operating limits and its technical specifications.

The Technical Specifications for $40 \mathrm{MW}$ and $60 \mathrm{MW}$ operation for the High Flux Beam Reactor (HFBR) located at Brookhaven National Laboratory (BNL) were reviewed for conformance to the Final Safety Analysis Report and its Addenda to enhance the safety of HFBR operations. Additionally, the Operations Procedure Manual(OPM) was reviewed for any inconsistencies between the FSAR or the Technical Specifications.

To ensure safe operation, the limiting value for a parameter as allowed by Technical Specifications should be more conservative than the value of that parameter used in the accident analysis. Also, the field setpoint on the limit of the parameter should be more conservative than the Technical Specification limit. These criteria ensure that the accident analysis covers the actual plant performance, and that the field settings allow for instrument drift.

\section{IV.1.1 Pony Motor Trip Settings (60 MW Operation)(Section 3.3.1 of HFBR Tech. Specs.)}

According to the Technical Specifications, during normal operation when the pony motors (60 MW) are not coupled to the primary pumps the normal reading for the current is 2.5 amps. The scram settings on 2/2 logic are 0.5 amps (low) and 7 amps (high). However, the $60 \mathrm{MW}$ Addendum to the FSAR indicates that the low current trip is at 1.0 amps. Although either trip setting will indicate an open circuit, the accident analysis value should not be higher than the Technical Specification limit. 
IV.1.2 Design Capacity of the Pony Motors (60 MW Operation)(Section 4.3.1.2 of HFBR Tech. Specs.)

Another conflict between the $60 \mathrm{MW}$ Addendum to the FSAR and the $60 \mathrm{MW}$ Technical Specifications is the design capacity of the pony motor batteries. The $60 \mathrm{MW}$ Addendum to the FSAR indicates a design capacity for approximately 6-2/3 hours and the $60 \mathrm{MW}$ Technical Specifications indicates a design capacity of 2 hours. Although just three minutes of forced cooling by the pony motor driven primary pumps is probably adequate $(60 \mathrm{MW})$, post trip, the specification of the design capacity of the batteries in the accident analysis should be less than the limit established by the Technical Specifications.

\section{IV.1.3 Offsite Dose Guidelines(Section $2.1 .1 \& 2.2 .1$ )}

DOE Order 5480.6, Safety of Department of Energy-Owned Nuclear Reactors, Section 8a provides a reference to the application of 10 CFR Part 100 for significant impacts on dose commitments when considering reactor siting or modifications of an existing reactor. Currently, DOE Order 5480.1A, Chapter XI is still being used for DOE dose limits for uncontrolled areas, however the portions of this order which pertain to doses to the public and environmental releases is being replaced by Draft Order $5400 . X X$ in the near future. Additionally, the portions of DOE Order 5480.1A, Chapter XI which pertain to radiation protection for workers has been replaced by DOE Order 5480.11, dated January 1 , 1989. When making any modifications to the HFBR Technical Specifications this information should be considered.

IV.1.4 Valve Type in Line P118 (Section 2.1.3)

The FSAR and the PDM indicate that there is a globe valve in line P118. However, the Technical Specifications refer to the valve as a gate valve. The Technical Specifications should be updated to reflect the proper nomenclature for systems and components.

\section{IV.1.5 MCHFR during a Loss of Cover Gas Pressure Accident(Section 2.1.3)}

For the loss of cover gas pressure accident the FSAR reports the MCHFR at 135 psig as 3.33, while the Technical Specifications report the MCHFR at 135 psig as 2.51. The documents should be updated to reflect the actual value of the MCHFR at 135 psig. 


\section{IV.1.6 Poison Solution System Cadmium Quantity (Section 3.3.6)}

The terminology reported in the Technical Specifications for the poison solution concentration is not consistent with the FSAR terminology. The Technical Specifications report that the quantity of $\mathrm{Cd}$ in solution in the poison water tank must not be less than 1055 lbs. The FSAR reports that the poison solution tank will hold 350 gallons of solution containing 3300 lbs of $\mathrm{Cd}\left(\mathrm{NO}_{3}\right)_{2} \bullet 4 \mathrm{H}_{2} \mathrm{O}$ dissolved in water. Efforts should be taken to ensure that the Technical Specifications are consistent with the FSAR.

\section{IV.1.7 Emergency Neutron Channels (Section 3.9)}

The emergency neutron channel indicators are not an indication of absolute power and are needed only to ensure reactor shutdown in the event of a control rod malfunction in conjunction with a loss of ac power. The Technical Specifications state that the reactor shall not be operated unless $1 / 3$ of the emergency neutron channel indicators are operable. However, to ensure the reactor is shutdown after a power outage it may be desirable to change this requirement to $2 / 3$ emergency neutron channel indicators are operable to provide redundancy.

\section{IV.1.8 Removal of Experiment Thimbles (Section 6.1.3)}

Section 6.1.3, item (1) of the Technical Specifications describes the removal of in-core fast thimbles V-15 or V-16 to be replaced by experiments directly in contact with the primary coolant. What precautions are taken to prevent leakage of the primary coolant when the thimble is removed and replaced?

\section{IV.1.9 Accident Analyses Calculations in the FSAR}

Most of the safety related thermal - hydraulics calculations (fuel surface and center line temperatures, etc.), were based on a model "TIGR4C". It is essential that this computer model be thoroughly validated and continuously updated to include up-to-date correlations. It is not clear from the FSAR or other available literature whether such steps have been taken or not. For example, some of the correlations used to determine heat transfer coefficients [Dittus - Boelter and Jens -Lottes] may not be the most appropriate correlations for the HFBR accident analyses. During some of the analyzed accidents the mass flow rate varied considerably (1000 - 18000 GPM), the temperature difference 
between the wall and the bulk fluid often exceeded $100^{\circ} \mathrm{F}$ and the operating pressure was as low as 50 psia. Under these conditions, use of the Dittus - Boelter or Jens - Lottes correlations must be quantitatively justified.

Documentation on TIGR4C has been made available recently and is currently under review.

\section{IV.1.10 Calculation of CHF in HFBR}

Both the original FSAR and Addendum to FSAR for $60 \mathrm{MW}$ Operation provided sketchy details on the calculation of CHF in HFBR. Both reports indicated that the Bernath Correlation was used to evaluate CHF in HFBR. However, in the original FSAR it was pointed out that the Bernath Correlation CHF predictions were divided by a safety factor of numerical value 1.4 to account for variations in geometrical and operating conditions between the correlation and HFBR. In this context it should be noted that the Bernath Correlation was developed for upflow of water in tubes and annuli whereas in the HFBR the water (D2O) flows downward in the rectangular channels. As mentioned earlier the factor 1.4 was presumably used to account for these differences. Independent calculations revealed that no such safety factor was used to calculate CHF in the Addendum to FSAR for $60 \mathrm{MW}$ Operation. Additionally, the calculations showed that no safety factor may be necessary to account for geometry but certainly one is needed to account for the downward flow direction. Until one accurately accounts for the effect of downward flow direction on CHF, it may not be appropriate to simply use the Bernath correlation to predict $\mathrm{CHF}$ in the HFBR. This should not, however, restrain low power restart in view of the large margin of safety (CHFR $>4$ in most cases) associated with low power operation.

\section{IV.1.11 Beam Tube Surveillance}

The Advisory Committee on Nuclear Facility Safety Subcommittee on the HFBR has raised a number of questions concerning the issue of beam tube integrity. The main concern is for brittle failure in the harsh environment of radiation heating. The Technical Specifications have been revised to include Sections 3.15 and 4.15 (40 MW) and Sections 3.14 and 4.14 (60 MW) entitled "Material Surveillance Program". The material surveillance includes the sampling of control rod followers which experience a radiation field similar to that seen by the beam tubes on intervals of $75,00 \mathrm{MWd}$ and is intended to satisfy this requirement. However, this is an indirect method and the indicated period between samplings is long, 5 years, at the estimated rate of 15,000 MWd operation per year. Since the integrity of the beam tubes has raised a number of questions, periodic beam tube surveillance would be included as part of the Technical Specifications. Non-destructive failure detection procedures that are based on $X$ rays or ultrasonics to measure beam tube thickness distributions and to detect skin cracks and pits should 
be evaluated for acceptable surveillance techniques. If such surveillance techniques are feasible then we recommend that they be implemented in the Technical Specifications on three-month intervals.

The survivability of the beam tube seal caps under jet impingement conditions cannot be assured by direct examination because of their remote location. The Technical Specifications have been revised to include Sections 3.18 and 4.18 (40MW) and Sections 3.17 and 4.17 (60 MW) entitled "Reactor Vessel Leakage" to attempt to satisfy this requirement. The $\mathrm{CO}_{2}$ cavity is sampled for tritium on a weekly bases as an indication of $\mathrm{D}_{2} \mathrm{O}$ leakage in the seal cap region. Although this is not as acceptable as physical observation it is probably the best that can be attained under the circumstance.

\section{IV.1.12 Control Rod Settings for a Freshly Fueled Core}

The full insertion of the auxiliary control rods must be assured during a fresh fuel configuration. Section 3.2.5 of the Technical Specifications specifies that the main and auxiliary control rods must be balanced with respect to one another (i.e, the distance of the main and auxiliary control rods from the core midplane is equal) unless the auxiliary rod bank is fully inserted (15 inches).

Normally with an equilibrium core, the critical position for the control rods is approximately 13.5 inches. However, for a freshly fueled core an approach to critical will need to be performed before operating at full power since the critical control rod position can not be accurately predicted for this more reactive condition. Additionally, the fresh fuel core will result in an unbalanced configuration since the main control rods will have to be inserted approximately 16 inches until fuel burnup will allow a balancing of the main and auxiliary control rods.

This situation was addressed in the auxiliary rod break accident discussed in the accident analysis section of the 1982 FSAR Addendum (Sect. 14.5.3.2). The discussion there suggested that if this situation arose then lower power limit restrictions would be implemented by administrative control. In fact, this situation did arise several times but the operation continued with the rods in a less withdrawn position, but without the promised power limitation procedures. This culminated in an Unusual Occurrence Report. The restriction on reactor power until the control rods can be balanced should be specified in the Technical Specifications. 
IV.2.0

\section{LIST OF SYSTEMS AND EQUIPMENT REQUIRED TO DETECT AND MTTIGATE HFBR FSAR DESIGN BASIS ACCIDENTS}

In most of the DBA analyses presented in the High Flux Beam Reactor (HFBR) Final Safety Analysis Report (FSAR), failure of a system or a group of systems cause emergency shutdown through an automatic scram. Safe and successful shutdown of the reactor after initial scram depends on satisfactory functioning of various systems and equipment that are available to mitigate DBA. The primary purpose of most of these systems is to provide adequate cooling of the reactor core after shutdown. The original FSAR for $40 \mathrm{MW}$ operation indicates that following shutdown the core is adequately cooled by natural circulation of heavy water residing in the reactor vessel. We concur with this conclusion. However, we would like to point out that due to availability of various mitigating systems that were introduced in recent modifications for $60 \mathrm{MW}$ operation (pony motors, for example), reliance on natural circulation for low power restart should be treated as a last resort. If one bears this in mind, then the requirements for systems and components to mitigate DBA following steady operation at $40 \mathrm{MW}$ are very similar to those corresponding to higher power levels (60 MW for example). Hence, it was decided to develop the list of required systems based on the FSAR for 60 MW operation. This list is expected to be conservative and yet practical without any modifications to the presently existing systems configuration. Additionally, the DBA analyses presented in the original FSAR for $40 M W$ operation were identified as obsolete in the Guide to HFBR Safety Analysis and the FSAR for $60 \mathrm{MW}$ Operation provides a modified and improved DBA analyses section.

Success criteria associated with the reactor core cooling following shutdown after steady operation at $60 \mathrm{MW}$ can be given as:

1. Forced circulation of heavy water through the core (GPM $\geq 1000$ ) for at least three minutes after the reactor shutdown by : (a) 1 out of 2 primary pumps or (b) 1 out of 2 pony motor driven primary pumps, or (c) 1 out of 2 shutdown pumps, and

2. Light water flow through the secondary of both the primary and shutdown heat exchangers provided by: (a) at least 1 out of 5 secondary coolant pumps, or (b) by manual opening of gravity feed line or cross connection feed line or fire hydrant feed line, or domestic water feed line. 
3. In case of loss of forced circulation through the core after three minutes, natural circulation of pool water in the pressure vessel enabled by automatic opening of flow reversal valves; during this phase of cooling the reactor needs to be depressurized to ensure low core temperatures as well as to enable steam condensation.

In the original design of HFBR and during the later modifications, several systems and components were incorporated to meet the criteria highlighted above. Together these systems provide various levels of depth in redundancy. A list of these systems is reproduced as Appendix-A of this report.

The scope of the present work is to identify the status and availability of each of these systems following a DBA, and to compile a list of systems and components that are required to mitigate the accident. In compiling the list, particular emphasis was given to parameter values used for automatic initiations or for manual action decisions, and equipment required to function for DBA detection and mitigation. The following sections list the major systems required for each of the design basis accidents. A condensed version of the list is presented in tabular form as Table 1. 
Table 1. List of Systems/Components Required by HFBR-FSAR DBA ${ }^{\dagger}$

\begin{tabular}{|c|c|c|c|c|c|c|c|c|c|c|c|c|c|c|c|c|c|c|c|}
\hline \multirow[b]{2}{*}{$\begin{array}{c}\text { Inittator } \\
\text { No. }\end{array}$} & \multirow[b]{2}{*}{\begin{tabular}{|l} 
Auto \\
Scrams
\end{tabular}} & \multicolumn{3}{|c|}{ REACTOR TRI' } & \multicolumn{2}{|c|}{ P'RIMARY P'UMPS } & \multicolumn{2}{|c|}{ PONY MOTORS } & \multicolumn{2}{|c|}{ SIIUTIDOWN PUMP } & \multicolumn{9}{|c|}{ SECONDARY COOLING RV DEPRESSURIZATION } \\
\hline & & Setback & $\begin{array}{c}\text { Manual } \\
\text { Scramt }\end{array}$ & $\begin{array}{l}\text { Polson } \\
\text { Water } \\
\end{array}$ & GA101A & GA101B & GA101A & GA101B & GA102A & GA102B & \begin{tabular}{|c|} 
No. of Pumps $_{\text {und }}$ \\
Required
\end{tabular} & $\begin{array}{c}\text { Gravity } \\
\text { Feed } \\
\end{array}$ & $\begin{array}{c}\text { Cross } \\
\text { Connection }\end{array}$ & $\begin{array}{c}\text { Other } \\
\text { Systems }\end{array}$ & HCE 102 & $\begin{array}{l}P 102 A, B \\
P 300 A, B \\
\end{array}$ & $\begin{array}{c}\text { Steam } \\
\text { Condensing }\end{array}$ & $\begin{array}{c}\text { D2O } \\
\text { Makkeup } \\
\end{array}$ & $\begin{array}{c}\text { Natural } \\
\text { Cinculation }\end{array}$ \\
\hline IV.2.1.1 & YES & - & $\%$ & MAN & $8 / 1$ & $1 / 4$ & AUTO & \% & 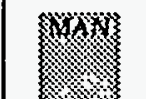 & AUTO: & $1 / 1 /$ & MAN & MAN & MAN & AUTO & 济 & MAN & MAN & MAN \\
\hline IV.2.1.2 & YES & - & 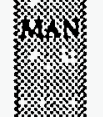 & MAN & $8 / \%$ & $1 / 1 /$ & 1uro & 13. & 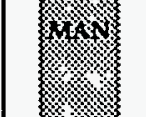 & ruño & $\frac{7}{1} /$ & $8 \%$ & Man: & MAN & औưro & 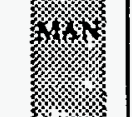 & MAN & MAN & MAN \\
\hline IV.22 & $\bullet$ & - & & 0 & $\frac{1}{1 /}$ & $1 / 1 / 1$ & P्s & \$. & 2 & ?ै? & $78 \%$ & 19 & 8 & 0 & $\sqrt[4]{4}$ & & 0 & 0 & 0 \\
\hline IV.23 & YES & - & 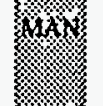 & MAN & $8 / 1$ & 的, & AUTO & 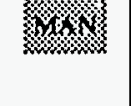 & 1 & Auto & $3^{10+5}$ & Kay & 学 & MAN & AUTO & $\sqrt{4}$ & MAN & MAN & MAN \\
\hline IV.24 & - & YES. & (x) & MAN & $\hat{\mathbf{A}}$ & $\stackrel{A}{*}$ & 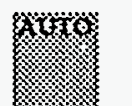 & MAN & MAN & W & 8 & $x$ & xis & MAN & A & 18 & MAN & MAN & MAN \\
\hline $\operatorname{IV} 2.5$ & YES & - & 3 & MAN & 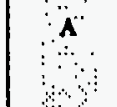 & ? & 2 & MAN & MAN & 40 & $\stackrel{106}{8}$ & 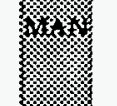 & \% & MAN & Puto & 19. & MAN & MAN & MAN \\
\hline IV 2.6 & YES & - & & MAN & $\mathrm{A}$ & 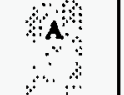 & 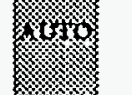 & MAN & MAN & 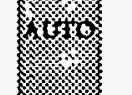 & $10 \%$ & 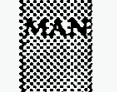 & 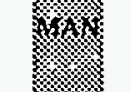 & MAN & Aứo & 4 & MAN & MAN & MAN \\
\hline IV $27^{\circ}$ & YES & - & 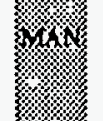 & MAN & $\mathbf{A}$ & ⿵ & X & MAN & MAN & x & \%० & 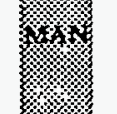 & 18, & MAN & outo & צra & MAN & MAN & MAN \\
\hline IV.28 & YES & - & 将厌 & MAN & $1 / 1 /$ & $9 /$ & $\begin{array}{l}\text { AUTO } \\
\qquad\end{array}$ & MAN & MAN & Auro & 1ot & 紋 & \% & MAN & AUTo & 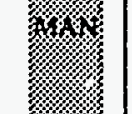 & MAN & MAN & MAN \\
\hline IV.2.9 & YES & - & צis & MAN & B, & 的, & Auro & MAN & MAN & भüo: & 18 & & & MAN & Aứro & 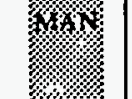 & MAN & MAN & MAN \\
\hline IV. $210^{\circ}$ & YES & - & \% & MAN & $\mathbf{A}$ & $\mathbf{A}$ & צY & MAN & MAN & & 705 & $3 r$ & 3 & MAN & Auto & 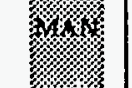 & MAN & MAN & MAN \\
\hline IV.2.11* & YES & - & 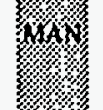 & MAN & $\hat{A}$ & 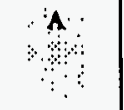 & (xim & MAN & MAN & 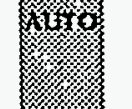 & 10 & 19y & 4 & MAN & AUTo & 4: & MAN & MAN & MAN \\
\hline IV.212 & YES & - & 综 & MAN & $8 / 1$ & $\hat{\imath}$ & 約 & rany, & MAN & KT: & अ. & $4=$ & 1. & MAN & \&uto & 3 & MAN & MAN & MAN \\
\hline IV $2.13^{\circ}$ & YES & - & \% & MAN & $18 \%$ & $\$ \%$ & $\cos n$ & soys. & "exxy, & "cosfos, & ofs & 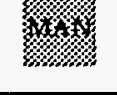 & \% & MAN & Yuto: & 219: & MAN & MAN & MAN \\
\hline $\begin{array}{l}0 \text { - Usual } \\
- \text { - Assun } \\
t=\text { See no }\end{array}$ & & $\begin{array}{l}\text { own proce } \\
\text { at fuel mel }\end{array}$ & $\begin{array}{l}\text { edure } \\
\text { eit s loce }\end{array}$ & d doc & affec & . & formans & & $\begin{array}{l}\text { Syster } \\
\text { //, syster } \\
\text { Syster }\end{array}$ & $\begin{array}{l}\text { ns required } \\
\text { ns that act as } \\
\text { ns failed or }\end{array}$ & preferred sh & $\begin{array}{l}\text { cutdown } \\
\text { cup } \\
\text { gerational }\end{array}$ & 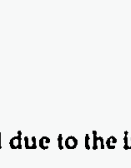 & iator & & & & & \\
\hline
\end{tabular}


Table 1. List of Systems/Components Required by HFBR-FSAR DBA (cont.)

INTIATOR \#

IV.2.1.1

IV.2.1.2

IV.2.2

IV.2.3

1V.2.4

IV.2.5

IV.2.6

IV.2.7

IV.2.8

IV.2.9

IV.2.10

IV.2.11

IV.2.12

IV.2.13

\section{INITIATOR}

Loss of Commercial Power. Short Duration

Loss of Commercial Power. Prolonged Duration

Error in Placement of Fuel Element During Refueling

Accidental Depressurization due to Opening of $\mathrm{HCe}-102$

Loss of Secondary Coolant Pump

Uncontrolled Rod Withdrawl

Accidental Throttling of Primary Flow Control Valves

Fuel Channel Blockage

Loss of Power to Primary Pumps

Accidental Opening of Manual Relief Valve in P-118

Thimble Flooding Accident

Auxiliary Rod Break Accident

Seizure of Primary Pump

Primary System Pipe Break

\section{Primary Pump Status}

A Operational

B Available, but conditional

C Coast Down, but breakers are closed

D Not available due to Pump Seizure or Loss of Commercial Power.

\section{OTHER SYMBOLS}

MAN Manual

AUTO Automatic

COND Conditional

FAIL Failed or Assumed fail 


\section{IV.2.1 Initiator: Loss of Commercial Power to the Plant}

Requirement for systems and equipment to mitigate this accident depends on the duration of power loss.

\section{IV.2.1.1 Condition: Short Duration ( $<3$ Secs)}

Power outage of short duration, typically 1-2 secs, is very frequent. During these situation the system performance is as follows:

Reactor Trip: Automatic scram is initiated $0.1 \mathrm{sec}$ after the power failure due to power loss to the rod drive clutches. The manual scram from the control room serves as the backup if the autoscram fails.

Primary Cooling: The primary pumps trip, and the coastdown ensues. But, the circuit breakers which are equipped with low voltage time delay circuits, remain closed which enable startup of primary pumps upon power recovery. In this case the auto shutdown pump and pony motor (60 MW) (which automatically enter the flow circulation network) provide first level redundancy. The remaining systems, including the other shut down pump and pony motor (60 MW) (which can be started from the control room) and the flow reversal valves and steam condensing equipment, provide additional redundancy.

Secondary Cooling: Immediately upon power loss, the secondary coolant pumps trip and the coastdown ensues. From the documentation provided it is not clear whether the circuit breakers remain closed or open. Therefore it is assumed that manual action from the control room is needed to restart the pumps. If all the pumps (5 out of 5 ) fail to restart, the operator needs to open the gravity feed line and/or the cross-connecting feed line to the primary heat exchangers.

Reactor Vessel Depressurization: If both primary and secondary pumps restart following the power recovery, it is not required to depressurize the system. But in case they fail, automatic depressurization valve $\mathrm{HCe}-102$ opens and the reactor vessel undergoes depressurization. Failure of $\mathrm{HCe}-102$ to automatically open should be compensated by manual opening of P-102, $\mathrm{P} 300 \mathrm{~A}$ or $\mathrm{P} 300 \mathrm{~B}$.

End Result: If both primary and secondary cooling systems restart following the power recovery it is possible to restart the reactor and reach operating power. 
Reactor Trip: Automatic scram of the reactor is initiated after 0.1 secs. The manual scram from the control room serves as the backup, but this action is not required unless the auto scram mechanism fails. The poison solution dumping, once again not a requirement unless the reactor scram mechanisms fail, provides additional redundancy for reactor shutdown.

Primary Cooling: The primary pumps trip and the coast down ensues. In this case, the automatically activated shutdown pump and pony motor $(60 \mathrm{MW})$ are sufficient to cool the reactor core. Thus, they are the only systems that are required to meet the success criteria on the primary side. The other systems that can be started from the control room (other pony motor (60 MW) and shutdown pump) serve as backup.

Secondary Cooling: The secondary pumps trip and coast down ensues. Although opening of check valve upon secondary pump failure feeds gravity driven flow to the shutdown heat exchangers, it is not clear whether that flow is adequate. Consequently, the requirement for secondary cooling is to manually open the gravity feed and cross connection feed lines to both the shutdown and primary heat exchangers. The fire hydrant feed and domestic water feed to the shutdown heat exchanger serve as backup.

Depressurization: Opening of primary pump circuit breakers trigger automatic opening of $\mathrm{HCe}-$ 102 which meets the requirement. The other three manual valves, P-102 and P300 A \&B, provide the backup.

Mitigating Systems: The mitigating systems are not required in this case unless the primary cooling is not sufficient. These systems, therefore, provide second level backup.

\section{IV.2.2 Initiator: Error in Placement of Fuel Element During Refueling}

There are no special failures or requirements associated with this class of initiators. If the error is detected during the reactor operation usual shutdown procedure can be used to shutdown the reactor and rearrange the fuel. 
IV.2.3 Initiator: Accidental Depressurization of Primary System due to Opening of HCe-102

Reactor Trip: Automatic Scram of the reactor occurs when the reactor vessel pressure reaches 180 psig. Such a scram would satisfy the requirement. The manual scram from the control room and the poison solution tank both serve as backups.

Primary Cooling: The Primary pumps are operational only until the reactor vessel pressure falls below the low-low pressure set point $(\mathrm{p}=120 \mathrm{psig}$ ). At that point the breakers open and the coastdown ensues. Because the duration of primary pump operation after the reactor scram is a function of the automatic depressurization valve HCe-102 opening size, no credit can be taken for primary pumps approximately 10 secs after the reactor scram. Therefore the realistic requirement for primary cooling is to automatically activate the pony motor $(60 \mathrm{MW})$ and shutdown pump which is already incorporated in the system design. In this case, the other set of pony motor $(60 \mathrm{MW})$ and shutdown pump serve as backup.

Secondary Cooling: The accidental depressurization of the primary system has little effect on the functioning of the secondary side systems. Therefore, the requirement for the secondary cooling would be continual operation of 1 out of 5 secondary cooling pumps. The rest of the secondary cooling systems provide backup that can be activated manually, if need be.

Depressurization: The initiator of present interest already covers it. If depressurization below $50 \mathrm{psig}$ is needed (such is the case during steam condensation) the P-102 and P-300A and P-300B valves can be opened manually.

Mitigation Systems: The requirement of mitigation systems is conditional subject to the failure of primary cooling.

\section{IV.2.4 Initiator: Loss of Secondary Coolant Pump}

Reactor Trip: The reactor trip in this class of initiators is through automatic setback; triggered when the heavy water inlet temperature reaches $141^{\circ} \mathrm{F}\left(60.5^{\circ} \mathrm{C}\right)$. No other reactor trip mechanism is required although both manual scram and poison dump are available as backup. 
Primary Cooling: Loss of secondary coolant pump is not expected to have any significance on the primary systems performance. Therefore, the primary cooling requirements are in accordance with the basic emergency shutdown procedures, and no special requirement exists.

Secondary Cooling: Loss of one or two pumps can be easily compensated by manually switching on other AC pumps available in the loop. The only requirement, therefore, is to ensure that at least one of the available pumps is switched on immediately to avert an increase in coolant temperature. Furthermore, the secondary cooling success criteria can also be met by manually opening the gravity feed line or cross connection feed line to the primary heat exchangers. The time available for operator response is on the order of 5-10 minutes. These manual operations serve as backup if the secondary pumps cannot be restored immediately.

Reactor Vessel Depressurization: R.V. Depressurization is not necessary to mitigate the accident. After the primary cooling requirements are met and the primary pumps are shutdown, the RV undergoes depressurization through automatic opening of $\mathrm{HCe}-102$.

\section{IV.2.5 Initiator: Uncontrolled Rod Withdrawal}

Reactor Trip: Automatic Scram when power reaches $48 \mathrm{MW}$ (assuming that the reactor was originally operating at $40 \mathrm{MW}$ ), which meets the requirement. Additionally manual scram is available as backup and in the extreme condition manual dump of poison water can be used to ensure a sub-critical state.

Remaining Systems: The requirements for primary, secondary, R.V. Depressurization and Mitigating systems are same as those associated with basic emergency shutdown procedure.

\section{IV.2.6 Initiator: Accidental Throttling of Primary Flow Control Valves}

Reactor Trip: The requirement is met by automatic scram initiated when:

1. Primary flow falls below 16,000 GPM, or

2. Core differential pressure less than $32 \mathrm{Psi}$.

Primary Cooling: The requirement for primary cooling is automatically met by primary pumps if only one control valve ( $\mathrm{HCV} 101 \mathrm{~A}$ or $\mathrm{B}$ ) is throttled. But if both valves are throttled then credit cannot be taken for either primary pumps or pony motors ( $60 \mathrm{MW}$ ) beyond 12 secs. In such an extreme condition the requirement for primary cooling is met by automatic opening of the 
shutdown pump feed line to the core. The other shutdown pump, which needs to be started manually from the control room, acts as a backup. Furthermore, it is also possible to manually reopen the control valves to resume primary pump flow through the core.

Remaining Systems: Accidental throttling of primary flow control valves has little effect on the secondary cooling systems, reactor vessel depressurization systems or other mitigating systems. The requirement for these systems is according to the emergency shutdown procedure.

\section{IV.2.7 Initiator: Fuel Channel Blockage}

Reactor Trip: There is no credible way of detecting fuel channel blockage prior to partial or total failure of fuel elements adjacent to the blocked channel. The only possibility is when a instrumented fuel element is adjacent to the blocked channel. Such a possibility is remote. Therefore, the only reliable mechanism for reactor trip by automatic scram is through detection of higher gamma ray activity in the primary coolant. Consequently, the reactor trip requirement is not met until the failure of one or more fuel elements induces higher gamma activity in the primary coolant.

Remaining Systems: The primary cooling 1 , secondary cooling, R.V. depressurization and other mitigating systems are not effected by this class of initiator. Requirements for primary and secondary cooling are same as those for basic emergency shutdown procedures.

\section{IV.2.8 Initiator: Loss of Power to Primary Pumps}

Reactor Trip: This requirement is met by automatic scram triggered by:

1. Primary pump current below the lower set point ( $35 \mathrm{amp}$ ), or

2. Primary flow rate is below the lower set point $(16,000 \mathrm{GPM})$, or

3. Core differential pressure less than 32 psi.

\footnotetext{
${ }^{1}$ Note: It is assumed that fuel melt is local and its effect on the primary systems /components performance is minimal. In reality, however, the overheating may cause fuel element bowing and complete fuel channel blockage that prevents natural circulation in the later stages. Because the analysis of melt propagation is complicated and the probability of occurrence of such an event is very low, it is assumed that the melt is local.
} 
Primary cooling: In this class of accidents, the primary pumps can not be given any credit beyond coastdown; i.e., it can not be assumed that operator actions would recover the primary pumps immediately. The primary cooling requirement is satisfied by flow from the pony motor ( 60 $M W)$ and the shutdown pump which come on-line automatically. The other set of pony motor $(60 \mathrm{MW})$ and shutdown pump that requires manual initiation provide a backup. Second level of redundancy is provided by the steam condensing equipment that is categorized as part of the mitigating systems.

Remaining Systems: The remaining systems, including secondary cooling systems and RV depressurization systems, are not effected by the initiator under discussion. These systems are to be controlled in accordance with the basic emergency shutdown procedure.

\section{IV.2.9 Initiator: Accidental Opening of Manual Relief Valve in Line P-118.}

Reactor Trip: This requirement is met by automatic scram action triggered by low reactor vessel pressure (RV pressure $\leq 180$ psig).

Primary Cooling: The primary pumps are operational until the RV pressure falls below 120 psig. Thereafter, the primary pumps coast down. During the period of their operation, the primary pumps provide enough flow to meet the success criteria. But the duration of their operation is subjected to the size of the relief valve opening. Hence credit cannot be taken for primary pumps beyond a minute after shutdown. After the primary pumps coastdown, the automatically initiated pony motor $(60 \mathrm{MW})$ and the shutdown pump meet the cooling requirements. The other set of pony motor $(60 \mathrm{MW})$ and shutdown pump which are available on manual initiation from the control room, are the backup.

Remaining System: Status quo as per emergency shutdown procedures.

Reactor Trip: The reactor is tripped by automatic scram triggered when the reactor power reaches $48 \mathrm{MW}$. The manual scram and poison solution dumping serve as first and second level backup, respectively.

Remaining Systems: The primary and secondary cooling systems and the rest of the mitigating systems are not affected by this class of initiators. So the requirements for various systems 
during shutdown are consistent with the basic emergency procedures. One exception, however, is that the initiator is associated with probable fuel cladding failure $(60 \mathrm{MW})$ (very small probability), due to simultaneous occurrence of rapid depressurization and overheating of the cladding, in spite of proper functioning of the mitigating systems.

\section{IV.2.11 Initiator: Auxiliary Rod Break Accident}

Reactor Trip: The reactor is tripped by automatic scram initiated when the reactor power reaches $48 \mathrm{MW}$. The manual scram and poison solution dumping provide first and second level redundancy.

Remaining Systems: Very similar to the previous case.

\section{IV.2.12 Initiator: Seizure of Primary Pump}

Reactor Trip: This requirement is fulfilled by automatic scram initiated when:

1. The Primary pump current exceeds the higher set point (150 amp), or

2. The flow rate falls below $16000 \mathrm{GPM}$, or

3. The core differential pressure falls below 32 psi.

Primary Cooling System: Although only one primary pump is available and pumping, the core flow rate is adequate to remove decay heat from the core. This operation of available primary pump for at least 3 minutes after shutdown meets the primary cooling requirement. The shutdown pumps (automatic and/or manual) and the manually initiated pony motor (60 MW) (automatically initiated pony motor $(60 \mathrm{MW})$ was assumed to be driving the seized primary pump) serve as backups.

Remaining Systems: The remaining systems that include secondary cooling systems, reactor vessel depressurization systems and the mitigating systems are not affected by this initiator. Therefore, their performance requirements are in accordance with the basic shutdown procedures. 


\section{IV.2.13 Initiator: Primary System Pipe Break}

The break is conservatively assumed to be a large LOCA that is capable of draining the core below the elevation of the outlet within 3 mins.

Reactor Trip: Automatic reactor trip is activated by:

1. Low liquid level $\left(<209^{\prime \prime}\right.$ hot $\left.\mathrm{D}_{2} \mathrm{O}\right)$, and/or

2. Low the pressure ( $<180$ psig).

The manual scram can also be initiated if the leak is detected prior to automatic scram. In such a case isolation of the break is possible. The poison solution dumping provides the backup.

Primary Cooling: The primary pumps are operational until the low-low liquid level logic is tripped and there after both primary pumps and shutdown pump are shutoff. The pony motor $(60 \mathrm{MW})$ or the primary pump coast down provide forced circulation through the core until the outlet of the vessel is uncovered. Obviously, time taken to reach the point of outlet uncovery depends on the break size and other systems performance. As pointed out earlier, it is assumed that the uncovery occurs within the initial 3 mins. In such a case, the core is cooled by natural circulation of residing heavy water in the reactor vessel. As pointed out at the start of this section, for power levels below $40 \mathrm{MW}$ natural circulation together with steam condensing is sufficient to adequately cool the reactor core. However, it should be pointed out that to avert core damage operator intervention is necessary.

Secondary Cooling: The secondary cooling systems are not affected by this class of initiators. Hence the secondary cooling systems performance requirements are exactly same as those corresponding to the basic emergency shutdown procedures.

Reactor Vessel Depressurization: The low-low level logic trip automatically opens the depressurization valve $\mathrm{HCe} 102$ and siphon break valve $\mathrm{HCe}-101 \mathrm{C}$ to depressurize the reactor vessel. From the reactor safety view point, faster depressurization would minimize the leakage rate and provides longer duration of forced circulation. In view of this, for initiators of this class it is advisable to depressurize the reactor vessel through manual opening of P-102 and $\mathrm{P}-300 \mathrm{~A}$ and $\mathrm{P}-300 \mathrm{~B}$ in addition to $\mathrm{HCe}-102$. Such procedures were already outlined in Operating Procedures Manual (OPM). For this purpose it is advisable to make P-102 and P300 A $\& B$ remotely operable from the control room. 
Mitigating Systems: Once the liquid level falls below the outlet, forced circulation through the core is not available. Thereafter, the core is cooled by natural circulation and steam condensing mechanisms. The secondary flow through shutdown and primary heat exchangers should continue to condense and recirculate the steam. In its absences it may be advisable to dump poison solution to makeup for loss of coolant by evaporation. 
IV.3.0

\section{REVIEW OF THE OPERATIONS PROCEDURES MANUAL}

The HFBR OPM was reviewed against the FSAR and its Addenda and the Technical Specifications to ensure consistency among the documents. Additionally, the procedures in the OPM were reviewed to determine if they were easily understandable and executable.

\section{IV.3.1 Time Requirement of Certain Procedures}

Throughout the OPM certain actions are called for by procedure. For example, the opening of the steam vent valves or the tripping of a motor. If these actions require movement outside of the control room and a significant period of time to accomplish this should be pointed out in the procedures.

\section{IV.3.2 NIAS and FVCA Alarms}

As a reminder to the operators the difference between the Nuclear Incident Alarm System (NIAS) and the Fuel Vault Criticality Alarm (FVCA). should be pointed out in the OPM.

\section{IV.3.3 Consistency of Scram Settings}

OPM chapter 2.1, Table 2.1-1 entitled Setback, Seismic Alarm, Depressurization, and Low-Low Action Settings Table presents some scram levels which conflict with those reported in the HFBR FSAR as follows:

1. The scram setting for high primary coolant gamma activity is reported in the HFBR FSAR Update for $60 \mathrm{MW}$ Operation as $100 \%$ of full scale; while in Table 2.1-1 the scram setting is reported as $75 \pm 5 \%$ of scale.

2. The pony motor ( $60 \mathrm{MW})$ normally run at 2.5 amps when uncoupled to the primary pumps. The scram setting reported in the HFBR FSAR for pony motor (60 MW) current is $1.0 \mathrm{amp}$ (low) and $7.0 \mathrm{amp}$ (high). However, Table 2.1-1 reports the scram setting as $1 \pm .5 \mathrm{amp}$ (low) and $6 \pm .5$ (high).

3. The primary pump motor scram settings are $150 \mathrm{~A}$ (high) and $35 \mathrm{~A}$ (low) as reported in the HFBR FSAR. However, in Table 2.1-1 the scram settings are indicated as $140 \pm 10 \mathrm{~A}$ (high) and $70 \pm 5 \mathrm{~A}$ (low).

Scram and trip settings should agree among all of the documents. Table 2.1-1 from OPM chapter 2.1 should be reviewed for inconsistencies against the FSAR and the Technical Specifications. 


\subsection{Net Time to Steam Generation}

OPM chapter 3.4, section 14.4 states that during a reactor vessel leak, depending upon the reactor level and the reactor power history, boiling may begin within 12 minutes. This item is currently being reviewed and a first estimate indicates that the 12 minutes to boiling may need to be revised. 


\section{CONCLUSIONS}

The Technical Specifications are well written and the items commented on should not delay the low power restart. However, a number of items were identified which should be resolved to maintain consistency between the Technical Specifications, the FSAR and the OPM. The relevant FSAR analytical bases are incorporated into the Technical Specifications. Additionally, the OPM is well written and easy to understand for the operators and does not require further modification before restart.

In some of the accidents analyzed (Fuel Channel Blockage (40 or $60 \mathrm{MW}$ ), for example), there is a probability $(<1 \mathrm{E}-3)$ that the hottest portion of the fuel element reaches $\mathrm{CHF}$ in spite of proper mitigating action by the automated systems. As a consequence of these accidents, it is possible that part of the fuel will melt. But, the melting is expected to be local and probably will have no effect on the system integrity. The fission products would be released in a controlled manner and the dose consequences will be within the guideline values for uncontrolled areas. Consequently, this does not pose a problem for HFBR low power restart.

The review also indicates that in most of DBAs analyzed in the HFBR-FSAR the systems and components required to mitigate the accident are automated. Systems that are controlled manually from the control room provide the first and second level redundancy. One exception is the Large LOCA (large primary system pipe break) where operator intervention is a necessity. In this accident operator may have to depressurize the reactor and vent steam through the steam vent valves ( $P-300 \mathrm{~A}$ and $\mathrm{B}$ ). The only modification suggested pertains to steam vent valves $P-300 A \& B$. It is recommended that for low power restart ( $40 \mathrm{MW})$ steam vent valves $P-300 \mathrm{~A} \& B$ be modified for remote manual operation and for $60 \mathrm{MW}$ operation they be modified to be fully automated in the event of a vessel or beam tube break. However, it is important to note that in spite of full automation of valves P-300 A\&B at $60 \mathrm{MW}$, the control room and operations level may be inaccessible during accidents for any manual mitigating actions (poison solution addition) due to the high radiation levels; therefore core damage may result. Additionally, although the pony motors are not required for low power restart they should be included as another level of forced cooling redundancy. With exception to these recommendations, the presently available systems structure is adequate for low power restart of HFBR. 
APPENDIX A 
APPENDIX A - HFBR SYSTEMS LIST - 1/26/90

\begin{tabular}{|c|c|c|c|c|c|c|}
\hline SYSTEM & FUNCTION & \begin{tabular}{|c|}
$\begin{array}{c}\text { OPERATIONAL } \\
\text { STATUS }\end{array}$ \\
\end{tabular} & $\begin{array}{l}\text { SAFETY } \\
\text { STATUS }\end{array}$ & DIRECT INTERFACES & \begin{tabular}{|c|}
$\begin{array}{c}\text { REQUIRED DIRECT } \\
\text { INTERFACES }\end{array}$ \\
\end{tabular} & $\begin{array}{l}\text { REFERENCES } \\
\& \text { COMMENTS } \\
\end{array}$ \\
\hline 1. Primary Coolant & (1) & Operating & Front line & 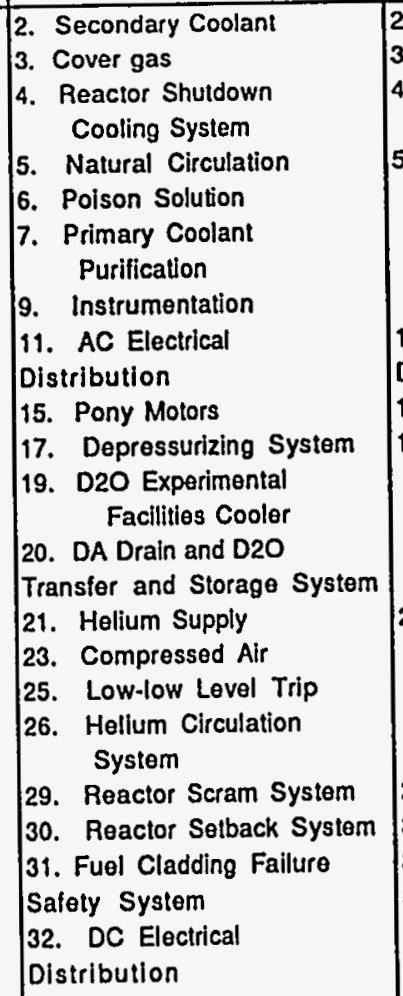 & \begin{tabular}{|l|} 
2. Secondary Coolant \\
3. Cover gas \\
4. Reactor Shutdown \\
Cooling System \\
5. Natural Circulation \\
11. AC Electrical \\
Distribution \\
15. Pony Motors \\
17. Depressurizing System \\
\\
21. Helium Supply \\
\\
29. Reactor Scram System \\
30. Reactor Setback System \\
31. Fuel Cladding Failure \\
Safety System \\
32. DC Electrical \\
Distribution
\end{tabular} & $\begin{array}{l}\text { Siphon break line and valve } \\
\text { considered part of primary } \\
\text { coolant system. }\end{array}$ \\
\hline 2. Secondary Coolant & $\begin{array}{l}\text { Coolant for primary D2O } \\
\text { cooler, D2O shutdown } \\
\text { cooler, thermal shield, } \\
\text { biological shield, } \\
\text { experimental facility }\end{array}$ & Operating & Front line & 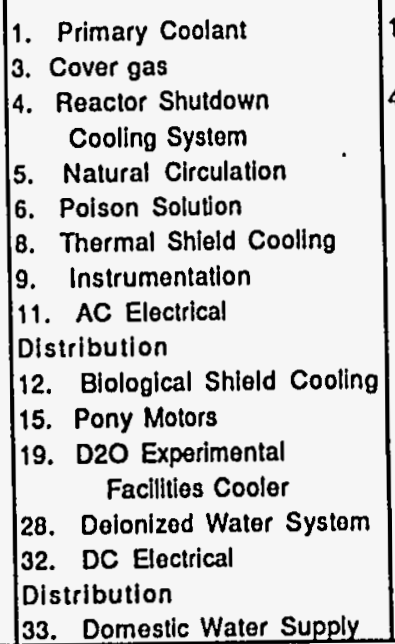 & $\begin{array}{l}\text { 1. Primary Coolant } \\
\text { 4. Reactor Shutdown } \\
\text { Cooling System }\end{array}$ & \\
\hline
\end{tabular}


APPENDIX A - HFBR SYSTEMS LIST - 1/26/90

\begin{tabular}{|c|c|c|c|c|c|c|}
\hline SYSTEM & FUNCTION & OPERATIONAL & SAFETY & DIRECT INTERFACES & REQUIRED DIRECT & REFERENCES \\
\hline & & STATUS & STATUS & & INTERFACES & \& COMMENTS \\
\hline 3. Helium Cover Gas & $\begin{array}{l}\text { Maintains } 200 \text { psig surge } \\
\text { volume pressure, provides } \\
\text { inen and compressible } \\
\text { volume to absorb liquid } \\
\text { surges, \& removes radiolytic } \\
\text { and corrosion gases }\end{array}$ & Operating & Support & 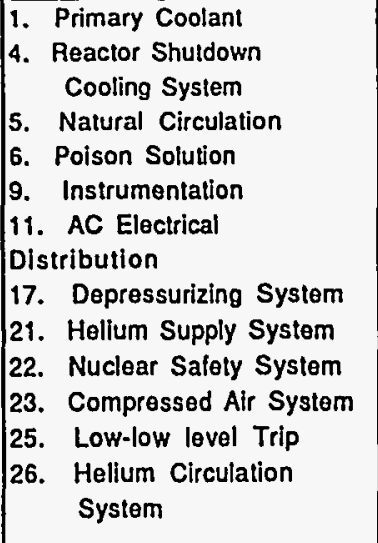 & $\begin{array}{l}\text { 1. Primary Coolant } \\
\text { 5. Natural Circulation } \\
\text { 17. Depressurizing System } \\
\text { 21. Helium Supply System } \\
\text { 26. Helium Circulation } \\
\text { System }\end{array}$ & \\
\hline $\begin{array}{l}\text { 4. Reactor Shutdown } \\
\text { Cooling System }\end{array}$ & Removal of decay heat & $1 / 2$ pumps oper. & 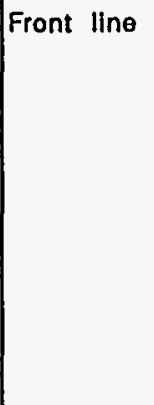 & $\begin{array}{l}\text { 1. Primary Coolant } \\
\text { 2. Secondary Coolant } \\
\text { 3. Cover Gas } \\
\text { 5. Natural Circulation } \\
\text { 11. AC Electrical } \\
\text { Distribution } \\
\text { 17. Depressurizing System } \\
\text { 22. Nuclear Safety System } \\
\text { 25. Low-low level Trip } \\
\text { 32. DC Electrical } \\
\text { Distribution }\end{array}$ & $\begin{array}{l}\text { 1. Primary Coolant } \\
\text { 2. Secondary Coolant } \\
\text { 11. AC Electrical } \\
\text { Distribution } \\
\text { 25. Low-low level Trip } \\
\text { 32. DC Electrical } \\
\text { Disiribution }\end{array}$ & \\
\hline 5. Natural Circulation & $\begin{array}{l}\text { Removes decay heat in the } \\
\text { event of loss of forced flow. }\end{array}$ & Standby & Front line & $\begin{array}{l}\text { 1. Primary Coolant } \\
\text { 2. Secondary Coolant } \\
\text { 3. Hellum Cover Gas } \\
\text { 4. Reactor Shutdown Cooling } \\
\text { System } \\
\text { 9. Instrumentation } \\
\text { 17. Depressurizing System } \\
\text { 20. DA Drain and D2O } \\
\text { Transfer and Storage System } \\
\text { 25. Low-low Level Trip }\end{array}$ & $\begin{array}{l}\text { 1. Primary Coolant } \\
\text { 17. Depressurizing System } \\
\text { 25. Low-low Level Trip }\end{array}$ & \\
\hline
\end{tabular}


APPENDIX A - HFBR SYSTEMS LIST - 1/26/90

\begin{tabular}{|c|c|c|c|c|c|c|}
\hline SYSTEM & FUNCTION & $\begin{array}{l}\text { OPERATIONAL } \\
\text { STATUS }\end{array}$ & $\begin{array}{l}\text { SAFETY } \\
\text { STATUS }\end{array}$ & DIRECT INTERFACES & $\begin{array}{c}\text { REQUIRED DIRECT } \\
\text { INTERFACES } \\
\end{array}$ & $\begin{array}{l}\text { REFERENCES } \\
\text { \& COMMENTS }\end{array}$ \\
\hline 6. Poison Solution & $\begin{array}{l}\text { Insures adequate shutdown in } \\
\text { the event of light water } \\
\text { flooding (cadmium nitrate } \\
\text { solution) and serves as a } \\
\text { backup to the control rod }\end{array}$ & Standby & Frontline & $\begin{array}{|ll|}\text { 1. } & \text { Primary Coolant } \\
\text { 2. } & \text { Secondary Coolant } \\
\text { 3. } & \text { Helium Cover Gas } \\
\text { 5. } & \text { Natural Circulation } \\
\text { 9. } & \text { Instrumentation } \\
\text { 17. } & \text { Depressurizing System } \\
\text { 21. } & \text { Helium Supply System } \\
\text { 33. } & \text { Domestic Water Supply }\end{array}$ & $\begin{array}{l}\text { 1. Primary Coolant } \\
\text { 33. Domestic Water Supply }\end{array}$ & 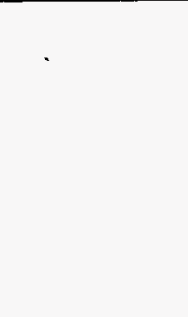 \\
\hline $\begin{array}{l}\text { 7. Primary Coolant } \\
\text { Purification }\end{array}$ & Puritier of D2O & Oporating & 西 & $\begin{array}{l}\text { 1. } \\
\text { 6rimary Coolant } \\
\text { 9. } \text { Poison Solution } \\
\text { 11. AC Electrical } \\
\text { Distribution } \\
\text { 20. DA Drain and D2O } \\
\text { Transier and Storage System }\end{array}$ & $\begin{array}{l}\text { 1. Primary Coolant } \\
\text { 11. AC Electrical } \\
\text { Distribution } \\
\text { 20. DA Drain and D2O } \\
\text { Transfer and Storage System }\end{array}$ & \\
\hline $\begin{array}{l}\text { 8. Thermal Shield } \\
\text { Cooling }\end{array}$ & $\begin{array}{l}\text { Removes heat generated by } \\
\text { radiation adsorption }\end{array}$ & 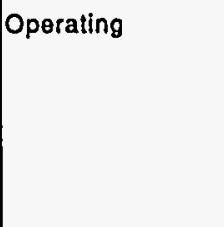 & None & $\begin{array}{l}\text { 2. Secondary Coolant } \\
\text { 9. Instrumentation } \\
\text { 11. AC Electrical } \\
\text { Distribution } \\
\text { 28. Deionized Water System } \\
\text { 33. Domestic Water Supply }\end{array}$ & $\begin{array}{l}\text { 2. Secondary Coolant } \\
\text { 11. AC Electrical } \\
\text { Distribution } \\
\text { 28. Deionized Water System }\end{array}$ & \\
\hline 9. Instrumentation & $\begin{array}{l}\text { Measures nuclear and non- } \\
\text { nuclear parameters }\end{array}$ & Operating & Support & $\begin{array}{l}\text { 1. Primary Coolant } \\
\text { 2. Secondary Coolant } \\
\text { 3. Cover gas } \\
\text { 4. Reactor Shutdown } \\
\text { Cooling System } \\
\text { 5. Natural Circulation } \\
\text { 6. Polson Solution } \\
\text { 7. Primary Coolant } \\
\text { Purification } \\
\text { 11. AC Electrical } \\
\text { Distrlbution } \\
\text { 14. Reactor Buliding } \\
\text { Containment } \\
\text { 15. Pony Motors } \\
\text { 17. Depressurizing System } \\
\text { 19. D2O Experimental } \\
\text { Facilities Cooler }\end{array}$ & $\begin{array}{l}\text { AC Electrical } \\
\text { 11. Alstribution } \\
\text { Distion }\end{array}$ & \\
\hline
\end{tabular}


APPENDIX A - HFBR SYSTEMS LIST - 1/26/90

\begin{tabular}{|c|c|c|c|c|c|c|}
\hline SYSTEM & FUNCTION & $\begin{array}{l}\text { OPERATIONAL } \\
\text { STATUS }\end{array}$ & $\begin{array}{l}\text { SAFETY } \\
\text { STATUS } \\
\end{array}$ & DIRECT INTERFACES & $\begin{array}{c}\text { REQUIRED DIRECT } \\
\text { INTERFACES }\end{array}$ & $\begin{array}{l}\text { REFERENCES } \\
\& \text { COMMENTS }\end{array}$ \\
\hline $\begin{array}{l}\text { 10. Control Rod Drive } \\
\text { 11. AC Electrical } \\
\text { Distribution }\end{array}$ & $\begin{array}{l}\text { Moves main and auxiliary } \\
\text { control rods } \\
\text { Provides AC motive power to } \\
\text { prime movers and instr. and } \\
\text { control components }\end{array}$ & $\begin{array}{l}\text { Operating } \\
\text { Operating }\end{array}$ & $\begin{array}{l}\text { Front line } \\
\text { Support }\end{array}$ & 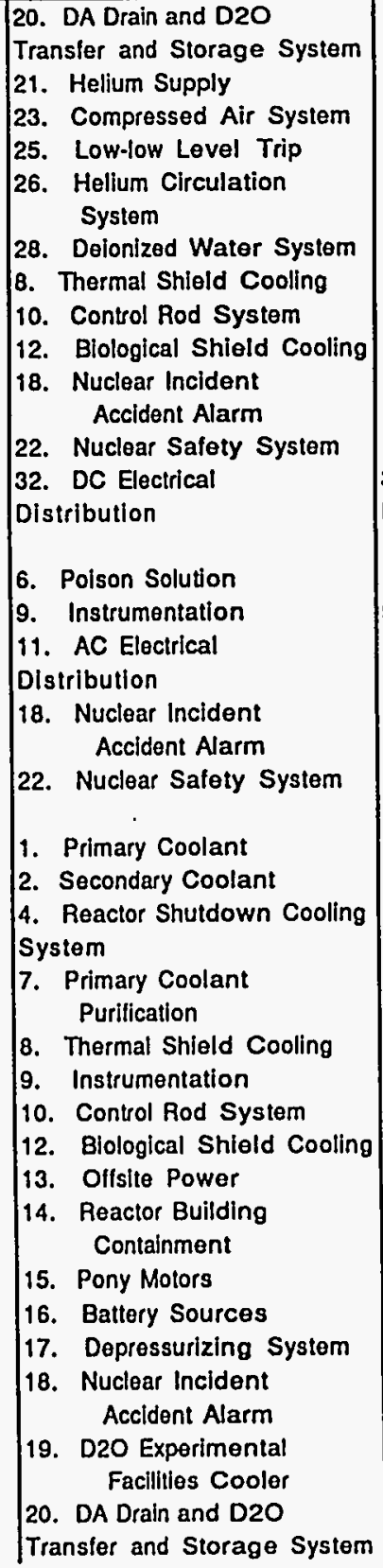 & $\begin{array}{l}\text { | } \\
\text { 32. DC Electrical } \\
\text { Distribution } \\
\text { 9. Instrumentation } \\
\text { 11. AC Electrical } \\
\text { Distribution } \\
\text { 18. Nuclear Incident } \\
\text { Accident Alarm } \\
\text { 22. Nuclear Salety System } \\
\text { 13. Oflsite Power } \\
\text { 16. Battery Sources } \\
\end{array}$ & \\
\hline
\end{tabular}


APPENDIX A - HFBR SYSTEMS LIST - 1/26/90

\begin{tabular}{|c|c|c|c|c|c|c|}
\hline & & & & $\begin{array}{ll}\text { 21. } & \text { Helium Supply } \\
\text { 22. } & \text { Nuclear Salely System }\end{array}$ & & \\
\hline SYSTEM & FUNCTION & $\begin{array}{l}\text { OPERATIONAL } \\
\text { STATUS } \\
\end{array}$ & $\begin{array}{l}\text { SAFETY } \\
\text { STATUS }\end{array}$ & DIRECT INTERFACES & $\begin{array}{l}\text { REQUIRED DIRECT } \\
\text { INTERFACES }\end{array}$ & $\begin{array}{l}\text { REFERENCES } \\
\text { \& COMMENTS }\end{array}$ \\
\hline $\begin{array}{l}\text { 12. Biological Shield } \\
\text { Cooling }\end{array}$ & $\begin{array}{l}\text { Removes heat from the } \\
\text { biological shield and also } \\
\text { provides the cooling lor the } \\
\text { Experimental Facility outside } \\
\text { of the thermal shield. }\end{array}$ & Operating & None & $\begin{array}{l}\text { 23. Compressed Air System } \\
\text { 24. Emergency Generator } \\
\text { 25. Low-low Level Trip } \\
\text { 26. Hellum Circulation } \\
\text { System } \\
\text { 28. Deionized Water System } \\
\text { 32. DC Electrical } \\
\text { Distribution } \\
\text { 33. Domestic Water Supply } \\
\text { 2. Secondary Coolant } \\
\text { 11. AC Electrical } \\
\text { Distribution } \\
\text { 28. Deionized Water } \\
\text { 33. Domestic Water Supply }\end{array}$ & $\begin{array}{l}\text { 24. Emergency Generator } \\
\text { 32. DC Electrical } \\
\text { Distribution } \\
\text { 2. Secondary Coolant } \\
\text { 19. AC Electrical } \\
\text { Distribution } \\
\text { 28. Deionized Water }\end{array}$ & \\
\hline 13. Olfsite Power & $\begin{array}{l}\text { Provides power to the BNL } \\
\text { iransformer building to } \\
\text { power the HFBR systems. }\end{array}$ & Operating & Suppont & $\begin{array}{l}\text { 11. AC Electrical } \\
\text { Distributlon }\end{array}$ & $\begin{array}{l}\text { 11. AC Electrical } \\
\text { Distribution }\end{array}$ & \\
\hline 14. Reactor Containment & $\begin{array}{l}\text { Retains the radioactive release } \\
\text { of any conceiveable reactor } \\
\text { accident. }\end{array}$ & Operating & 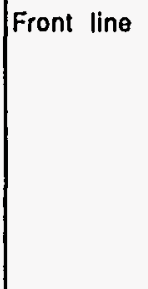 & $\begin{array}{l}\text { 9. Instrumentation } \\
\text { 11. AC Electrical } \\
\text { Distribution } \\
\text { 17. Depressurizing Valve } \\
\text { 18. Nuclear Incident } \\
\text { Accident Alarm } \\
\text { 23. Compressed Air System } \\
\text { 33. Domestic Waler Supply }\end{array}$ & $\begin{array}{l}\text { 18. Nuclear Incident } \\
\text { Accident Alarm }\end{array}$ & \\
\hline 15. Pony Motors & $\begin{array}{l}\text { Provides safe transistion to } \\
\text { llow reversal cooling. } \\
\text { Connected to main pumps. } \\
\text { Required for increase to } \\
60 \mathrm{MW}\end{array}$ & $1 / 2$ Operating & Front line & $\begin{array}{l}\text { 1. Primary Coolant } \\
\text { 2. Secondary Coolant } \\
\text { 3. Cover gas } \\
\text { 4. Reactor Shutdown } \\
\text { Cooling System } \\
\text { 5. Natural Circulation } \\
\text { 9. Instrumentation } \\
\text { 11. AC Electrical } \\
\text { Distribution } \\
\text { 25. Low-low level Trip } \\
\text { 32. DC Electrical } \\
\text { Distribution }\end{array}$ & $\begin{array}{l}\text { 1. Primary Coolant } \\
\text { 32. DC Electrical } \\
\text { Distribution }\end{array}$ & \\
\hline
\end{tabular}


APPENDIX A - HFBR SYSTEMS LIST - 1/26/90

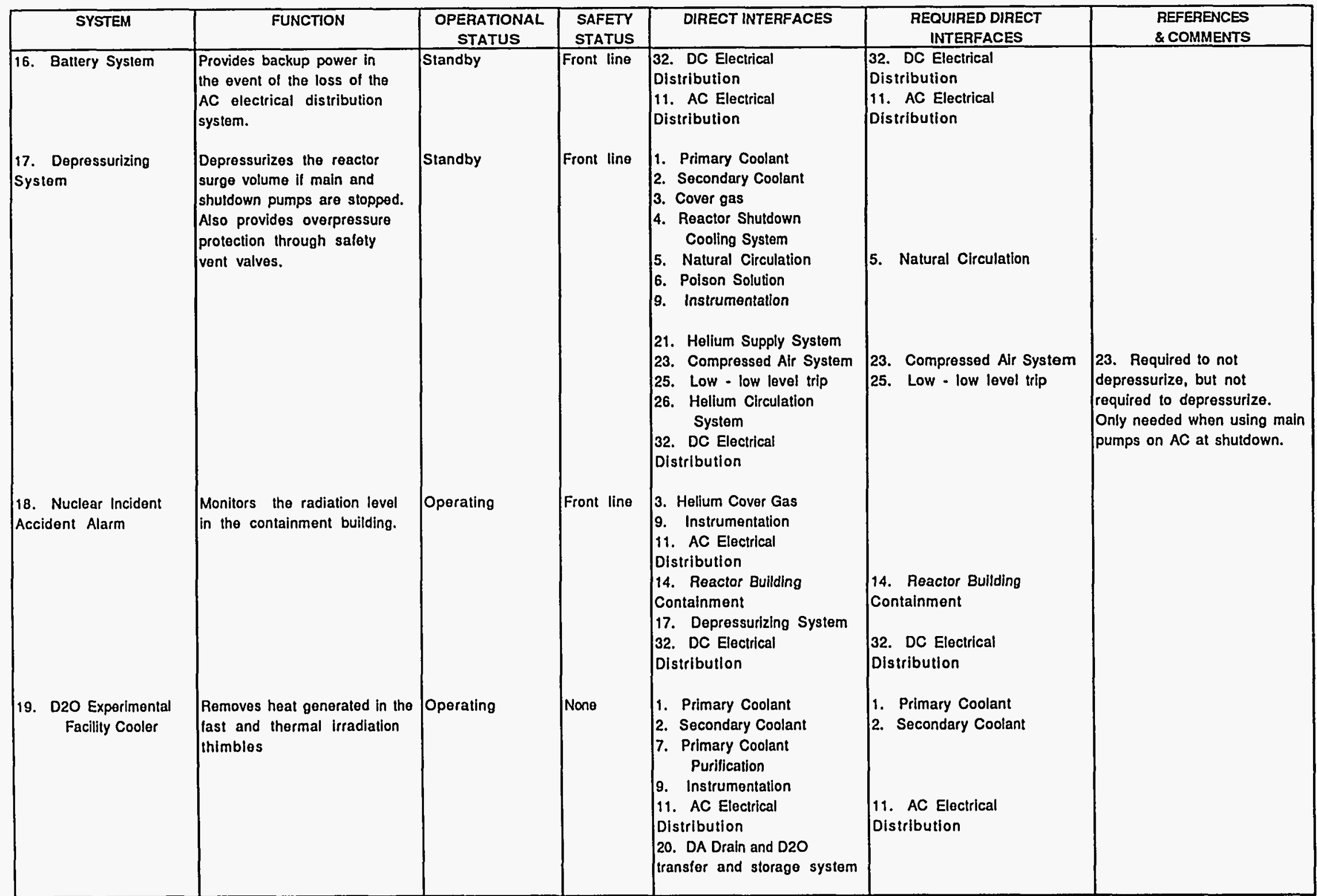


APPENDIX A - HFBR SYSTEMS LIST - 1/26/90

\begin{tabular}{|c|c|c|c|c|c|c|}
\hline SYSTEM & FUNCTION & $\begin{array}{l}\text { OPERATIONAL } \\
\text { STATUS }\end{array}$ & $\begin{array}{l}\text { SAFETY } \\
\text { STATUS }\end{array}$ & DIRECT INTERFACES & $\begin{array}{l}\text { REQUIRED DIRECT } \\
\text { INTERFACES }\end{array}$ & $\begin{array}{l}\text { REFERENCES } \\
\& \text { COMMENTS }\end{array}$ \\
\hline $\begin{array}{l}\text { 20. DA Drain and D2O } \\
\text { Transler and Storage } \\
\text { System }\end{array}$ & $\begin{array}{l}\text { Fills the various process } \\
\text { systems and replaces any lost } \\
\text { D2O, collects D2O drained } \\
\text { irom components (tank FA- } \\
\text { 101) stores a supply of D2O } \\
\text { in tank FA-102 lor } \\
\text { emergency primary makeup }\end{array}$ & Operating & Support & $\begin{array}{l}\text { 1. Primary Coolant } \\
\text { 4. Reactor Shutdown Cooling } \\
\text { System } \\
\text { 7. Primary Coolant } \\
\text { Purification } \\
\text { 9. Instrumentation } \\
\text { 11. AC Electrical } \\
\text { Distribution } \\
\text { 19. Shutdown HX } \\
\text { 24. Helium Supply System }\end{array}$ & 24. Helium Supply System & $\begin{array}{l}\text { 1. Required for makeup } \\
\text { following breach in primary } \\
\text { system. }\end{array}$ \\
\hline $\begin{array}{l}\text { 21. Helium Supply } \\
\text { Systom }\end{array}$ & $\begin{array}{l}\text { Provides high \& low pressure } \\
\text { helium for various processes }\end{array}$ & Operating & Support & $\begin{array}{l}\text { 1. Primary Coolant } \\
\text { 3. Cover Gas } \\
\text { 5. Natural Circulation } \\
\text { 6. Poison Solution } \\
\text { 11. AC Electrical } \\
\text { Distribution }\end{array}$ & 1. Primary Coolant & $\begin{array}{l}\text { 1. Required to open siphon } \\
\text { break valve. }\end{array}$ \\
\hline $\begin{array}{l}\text { 22. Nuclear Safety } \\
\text { System }\end{array}$ & $\begin{array}{l}\text { Provides automatic scram or } \\
\text { setback signals to the control } \\
\text { rod drive system. See Table } 4 \\
\text { and Table 5. }\end{array}$ & Operating & Front line & $\begin{array}{l}\text { 11. AC Electrical } \\
\text { Distribution } \\
9 . \quad \text { Instrumentation }\end{array}$ & $\begin{array}{l}\text { 11. AC Electrical } \\
\text { Distribution } \\
\text { 9. Instrumentation }\end{array}$ & \\
\hline $\begin{array}{l}\text { 23. Compressed Air } \\
\text { System }\end{array}$ & $\begin{array}{l}\text { Provides compressed air to } \\
\text { the reactor building and the } \\
\text { pumphouse }\end{array}$ & Operating & Support & $\begin{array}{l}\text { 3. Helium Cover Gas } \\
\text { 9. Instrumentation } \\
\text { 11. AC Electrical } \\
\text { Distributlon } \\
\text { 17. Depressurizing System } \\
\text { 33. Domestic Water Supply }\end{array}$ & $\begin{array}{l}\text { 11. AC Eloctrical } \\
\text { Distribution }\end{array}$ & \\
\hline $\begin{array}{l}\text { 24. Emergency Power } \\
\text { Generator }\end{array}$ & $\begin{array}{l}\text { Propane powered generator; } \\
\text { backup to the AC electrical } \\
\text { distribution system }\end{array}$ & Standby & Support & $\begin{array}{l}\text { 9. Instrumentation } \\
\text { 11. AC Electrical } \\
\text { Distribution } \\
\text { 27. Propane Supply } \\
\text { 33. Domestic Water Supply }\end{array}$ & $\begin{array}{l}\text { 11. AC Electrical } \\
\text { Distribution } \\
\text { 27. Propane Supply }\end{array}$ & \\
\hline $\begin{array}{l}\text { 25. Low - low level } \\
\text { irip }\end{array}$ & $\begin{array}{l}\text { Trips all pumps, opens the } \\
\text { flow reversal valves, the } \\
\text { depressurizing valve, and the } \\
\text { siphon break valve. }\end{array}$ & Standby & Front line & $\begin{array}{l}\text { 1. Primary Coolant } \\
\text { 5. Natural Clrculation } \\
\text { 9. Instrumentation } \\
\text { 11. AC Electrical } \\
\text { Distribution } \\
\text { 17. Depressurizing Valve } \\
\text { 23. Compressed Air System }\end{array}$ & $\begin{array}{l}\text { 5. Natural Circulation } \\
\text { 9. Instrumentation } \\
\text { 11. AC Electrical } \\
\text { Distribution } \\
\text { 17. Depressurizing Valve }\end{array}$ & \\
\hline
\end{tabular}


APPENDIX A - HFBR SYSTEMS LIST - 1/26/90

\begin{tabular}{|c|c|c|c|c|c|c|}
\hline SYSTEM & FUNCTION & $\begin{array}{l}\text { OPERATIONAL } \\
\text { STATUS }\end{array}$ & $\begin{array}{l}\text { SAFETY } \\
\text { STATUS }\end{array}$ & DIRECT INTERFACES & $\begin{array}{l}\text { REQUIRED DIRECT } \\
\text { INTERFACES }\end{array}$ & $\begin{array}{l}\text { REFERENCES } \\
\& \text { COMMENTS }\end{array}$ \\
\hline $\begin{array}{l}\text { 26. Helium Circulation } \\
\text { System } \\
\text { 27. Propane Supply }\end{array}$ & $\begin{array}{l}\text { Circulates helium from the } \\
\text { surge volume through } \\
\text { the recombiner and back } \\
\text { to the surge volume } \\
\text { Provides a propane supply to } \\
\text { to the emergency generator. }\end{array}$ & Standby & Front line & $\begin{array}{l}\text { 1. Primary Coolant } \\
\text { 3. Helium Cover Gas } \\
\text { 21. Helium Supply System } \\
\text { 24. Emergeney power } \\
\text { Generator }\end{array}$ & $\begin{array}{l}\text { 1. Primary Coolant } \\
\text { 21. Helium Supply System } \\
\text { 24. Emergency power } \\
\text { Generator }\end{array}$ & \\
\hline $\begin{array}{l}\text { 28. Deionized Water } \\
\text { system }\end{array}$ & $\begin{array}{l}\text { Provides coolant for the } \\
\text { biological and thermal shield } \\
\text { cooling systems }\end{array}$ & Operating & None & $\begin{array}{l}\text { 2. Secondary Coolant } \\
\text { 8. Thermal Shleld Cooling } \\
\text { 9. Instrumentation } \\
\text { 11. AC Electrical } \\
\text { Distribution } \\
\text { 12. Biological Shield Cooling } \\
\text { 33. Domestic Water Supply }\end{array}$ & $\begin{array}{l}\text { 2. Secondary Coolant } \\
\text { 11. AC Electrical } \\
\text { Distribution }\end{array}$ & \\
\hline $\begin{array}{l}\text { 29. Reactor Scram } \\
\text { System }\end{array}$ & $\begin{array}{l}\text { Protects the reactor from out } \\
\text { of limit conditions by scram } \\
\text { signals as outlined in Table } 4 \text {. }\end{array}$ & Operating & Front line & $\mid \begin{array}{l}\text { 9. Instrumentation } \\
11 . \quad A C \text { Electrical } \\
\text { Distribution }\end{array}$ & $\begin{array}{l}\text { 9. Instrumentation } \\
\text { 11. AC Electrical } \\
\text { Distribution }\end{array}$ & \\
\hline $\begin{array}{l}\text { 30. Reactor Setback } \\
\text { System }\end{array}$ & $\begin{array}{l}\text { Protects the reactor from out } \\
\text { of limit conditions by setback } \\
\text { signals as outlined in Table } 5 .\end{array}$ & Operating & Front line & $\begin{array}{l}\text { 9. Instrumentation } \\
\text { 11. AC Electrical } \\
\text { Distribution }\end{array}$ & $\begin{array}{l}\text { 9. Instrumentation } \\
\text { 11. AC Electrical } \\
\text { Distribution }\end{array}$ & \\
\hline $\begin{array}{l}\text { 31. Fuel Cladding } \\
\text { Failure Salety System }\end{array}$ & $\begin{array}{l}\text { Provides a scram signal when } \\
\text { breaches in the fuel cladding } \\
\text { are detected }\end{array}$ & Operating & Front line & $\begin{array}{l}\text { 1. Primary Coolant } \\
\text { 9. Instrumentation } \\
\text { 11. AC Electrical } \\
\text { Distribution }\end{array}$ & $\begin{array}{l}\text { 9. Instrumentation } \\
\text { 11. AC Electrical } \\
\text { Distribution }\end{array}$ & \\
\hline $\begin{array}{l}\text { 32. DC Electrical } \\
\text { Distribution }\end{array}$ & $\begin{array}{l}\text { Provides DC motive power to } \\
\text { prime movers and instr. and } \\
\text { control components }\end{array}$ & Standby & Front line & $\begin{array}{l}\text { 11. AC Electrical } \\
\text { Distribution } \\
\text { 16. Battery System } \\
\text { 24. Emergency Generator }\end{array}$ & $\begin{array}{l}\text { 11. AC Electrical } \\
\text { Distribution } \\
\text { 16. Battery System } \\
\text { 24. Emergency Generator }\end{array}$ & \\
\hline $\begin{array}{l}\text { 33. Domestic Water } \\
\text { Supply }\end{array}$ & $\begin{array}{l}\text { Light water supply for many } \\
\text { HFBR systems including } \\
\text { secondary water system } \\
\text { makeup, air compressor } \\
\text { cooling and emergency } \\
\text { generator cooling. }\end{array}$ & Operating & Support & $\begin{array}{l}\text { 2. Secondary Coolant } \\
\text { 6. Poison Solution } \\
\text { 8. Thermal Shleld Cooling } \\
\text { 11. AC Electrical } \\
\text { Distribution } \\
\text { 12. Biological Shield Cooling } \\
\text { 14. Reactor Containment } \\
\text { 23. Compressed Alr } \\
\text { System } \\
\text { 24. Emergency Power } \\
\text { Generator } \\
\text { 28. Deionized Water } \\
\text { System }\end{array}$ & $\begin{array}{l}\text { 6. Poison Solution } \\
\text { 24. Emergency Power } \\
\text { Generator }\end{array}$ & \\
\hline
\end{tabular}

